\title{
The Effect of Additional Nanoparticles Supplementation of Indonesian Bay Leaf (SyzigiumPolyanthum) on Blood Pressure in Pregnancy Hypertension
}

\author{
MiftahNurlaily El Akhlaq ${ }^{1 *}$ \\ ${ }^{1}$ PoltekkesKemenkes Semarang,Master of \\ Applied Science in Midwifery, \\ TirtoAgung Rd., Semarang,Jawa Tengah 50268, Indonesia \\ Suhartono ${ }^{3}$ \\ Department of Environmental Health, Faculty of Public \\ Health, Diponegoro University, \\ Prof. Sudarto Rd., Semarang,Jawa Tengah 50275, Indonesia
}

\author{
Suharyo Hadisaputro ${ }^{2}$ \\ PoltekkesKemenkes Semarang, Master of \\ Applied Science in Midwifery \\ TirtoAgung Rd., Semarang,Jawa Tengah 50268, Indonesia \\ Sri Sumarni ${ }^{4}$ \\ ${ }^{4}$ Poltekkes Kemenkes Semarang, Master of \\ Applied Science in Midwifery \\ TirtoAgung Rd., Semarang, Jawa Tengah 50268, Indonesia
}

\author{
M. Choiroel Anwar ${ }^{5}$ \\ PoltekkesKemenkes Semarang \\ Postgraduate Program of Imaging Diagnostic \\ TirtoAgung Rd., Semarang,Jawa Tengah 50268, \\ Indonesia
}

\begin{abstract}
Bay leaf (Syzygiumpolyanthum) or Daun Salam is one of the plants that has many benefits, one of them is to reduce blood pressure. The aim of this study is to prove the effect of adding nanoparticles supplementation of bay leaf (Syzygiumpolyanthum) to systolic and diastolic blood pressure in pregnancy hypertension.The study was quasi-experiment. 39 respondents were divided into 19 pregnant women in intervention group and 20 pregnant women in the control group. The intervention was given for 14 days by consumingnifedipine $10 \mathrm{mg}$ plus $80 \mathrm{mg}$ bay leaf nanoparticle capsules to the intervention group.The results of data analysis showed a decrease in systolic blood pressure $(p=0.000)$ and diastolic blood pressure ( $p=0.004)$ when compared with the control group, which means that there were differences in the mean systolic and diastolic blood pressure between the two groups after treatment. The addition of bay leaf nanoparticle supplementation $1 \times 80 \mathrm{mg}$ for 14 days affected the decrease in systolic and diastolic blood pressure in pregnancy hypertension. So that the supplementation of bay leaf nanoparticles can be used as adjunctive therapy in pregnancy hypertension
\end{abstract}

Keywords:- Bay leaf, Blood pressure, Gestational hypertension.

\section{INTRODUCTION}

Pregnancy hypertension is one of the causes of maternal morbidity and mortality in the world. Based on data from the World Health Organization (WHO), in 2015, there are approximately 289.000 cases of maternal mortality, and $14 \%$ of those cases are pregnancy hypertension.[1] The maternal mortality rate in Indonesia was 177 deaths per 100.000 live births in 2017.[2] The number of maternal mortality in Central Java, in 2017, was
475 cases. Most deaths are caused by pregnancy hypertension, with the percentage of $32,97 \%$, and the highest number of cases were coming from Brebes Regency.[3]The number of maternal mortality, in 2017, from this regency was 31 cases from 95/100.000 live births.[4]

Hypertension in pregnancy can be a severe condition if it is not treated. It is because of its emerged complications. $25 \%$ of pregnancy hypertension cases can turn into superimposed preeclampsia.[5]

To control these mentioned problems, the management of pregnancy hypertension can be done pharmacologically and non-pharmacologically. Pharmacological anti-hypertensive therapy is inseparable from its side effects. The side effects are ranging from: sleep disturbance, bronchospasm, decreased uteroplacental flow, fetal distress, or a dramatic decrease in magnesium.[6] Non-pharmacological therapy for hypertension that has been tried in clinical trials is the use of herbs, device-guidedbreathing, and other biofeedback.[7]

Indonesian Bay Leaf (Syzygiumpolyanthum) is a plant that has an anti-hypertensive effect because of its antioxidant content. Phenolic and flavonoids such as eugenol, kaempferol, and quercetin contribute to the antioxidant activity of bay leaves.[8] Processing of herbal ingredients using nanoparticle technology shows an increasing trend because the bioavailability of nanoparticles is considered to be better in the process of absorption of active ingredients by the small intestinal wall.[9] Previous research of hypertensive patients with treatment of drinking bay leaf decoction two times, showing the results that the bay leaf decoction water can 
reduce blood pressure because its minerals can dilate blood vessels.[10]

Referring to previous research, there has been no research on the provision of bay leaves with nanotechnology processing technology in hypertension that occurs in pregnancy. By considering the toxicity of the material, we, as researchers, are interested in conducting research to determine the effect of supplementation of bay leaf nanoparticles (Syzygiumpolyanthum) on systolic and diastolic blood pressure of pregnant women with pregnancy hypertension.

\section{OBJECTIVES}

This study aims to prove the effect of adding supplementation of bay leaf nanoparticles (Syzygiumpolyanthum) on the decrease in systolic and diastolic blood pressure of pregnant women with pregnancy hypertension.

\section{METHODS}

This study wasQuasi-Experiment with a nonrandomized pre-test and post-test with control group design. The reference population in this study were pregnant women of gestational age $>20$ weeks - 38 weeks with pregnancy hypertension. Samples in the intervention group were 19 people, and in the control group were 20 people. The intervention group was given $80 \mathrm{mg}$ bay leaf nanoparticles and $10 \mathrm{mg}$ nifedipine, while the control group was only given $10 \mathrm{mg}$ nifedipine.

The sampling technique uses a non-probability sampling method with the type of purposive sampling.

The instrument in this research is a digital tension meter which had been validated.

The data is collected after obtaining an ethical eligibility letter from the Health Research Ethics Committee (KEPK) RSUD Dr. Moewardi with letter number 1.398 / XII / HREC / 2019.

Analysis of blood pressure before and after treatment using a paired t-test, and to determine the differences between the two groups using the independent t-test.

\section{RESULTS}

\begin{tabular}{|c|c|c|}
\hline \multirow{2}{*}{ Variable } & \multicolumn{2}{|c|}{$p$-value* } \\
\cline { 2 - 3 } & Intervention & \\
\hline Systolic Blood Pressure & & 0.710 \\
\hline Pre & 0.280 & 0.943 \\
\hline Post & 0.185 & 0.097 \\
\hline Delta & 0.248 & 0.501 \\
\hline Diastolic Blood Pressure & & 0.380 \\
\hline Pre & 0.062 & 0.586 \\
\hline Dest & 0.285 & 0.203 \\
\hline
\end{tabular}

*Shapiro-Wilk

Table 1:- Normality Test

Table 1 shows the normality test of systolic and diastolic blood pressure. Normality test results show that the p-value is more than 0.05 , so it wrapped that the data are normally distributed so it can be continued using the parametric test.

\begin{tabular}{|c|c|c|c|}
\hline Systolic Blood Pressure & Intervention Group & \multicolumn{2}{|c|}{ Control Group } \\
\cline { 2 - 4 } & Mean \pm SD & Mean \pm SD & $p$ value \\
\hline Pre-test & $151.53 \pm 4.97$ & $151.20 \pm 6.27$ & $0.859 * *$ \\
\hline Post-test & $139.84 \pm 7.59$ & $151.40 \pm 6.96$ & $<0.001^{* *}$ \\
\hline Delta & $11.68 \pm 5.47$ & $-20 \pm 3.433$ & $<0.001^{* *}$ \\
\hline$p-$ value & $<0.001^{*}$ & $0.798^{*}$ & \\
\hline
\end{tabular}

* Paired $t$-test

** Independent t-test

Table 2:- Systolic Blood Pressure Result 
Table 2 illustrated the average systolic blood pressure in the intervention group. It was $151.53 \mathrm{mmHg}$ and decreased to $139.84 \mathrm{mmHg}$. The result of paired t-test analysis in the intervention group showed a $p$-value $<0.05$, which means that there was a difference in systolic blood pressure before and after the intervention.

While the mean systolic blood pressure in the control group was $151.20 \mathrm{mmHg}$, and it decreased into $151.40 \mathrm{mmHg}$. The result of paired t-test analysis in the control group showed a $p$-value $>0.05$, which means there was no difference in systolic blood pressure before and after the intervention.

Based on the results of the Independent t-test showed that the value of $p=0.859>0.05$, which means there was no difference in the average systolic blood pressure between the intervention group and the control group before being treated. After treatment, the result was $\mathrm{p}$ $=0.000<0.05$, which means that there was a difference in the average systolic blood pressure after being treated in the two groups

\begin{tabular}{|c|c|c|c|}
\hline $\begin{array}{c}\text { Diastolic Blood } \\
\text { Pressure }\end{array}$ & $\begin{array}{c}\text { Intervention } \\
\text { Group }\end{array}$ & \multicolumn{2}{|c|}{ Control Group } \\
\cline { 2 - 4 } & Mean \pm SD & Mean \pm SD & $p$ value \\
\hline Pre-test & $104.79 \pm 6.60$ & $106.20 \pm 9.54$ & $0.597^{* *}$ \\
\hline Post-test & $92.84 \pm 8.71$ & $101.85 \pm 9.33$ & $0.004^{* *}$ \\
\hline Delta & $11.95 \pm 5.642$ & $4.35 \pm 6.167$ & $<0.001^{* *}$ \\
\hline$p$ value & $<0.001^{*}$ & $0.005^{*}$ & \\
\hline
\end{tabular}

* Paired $t$-test

** Independent t-test

Table 3:- Diastolic Blood Pressure Result

Table 3 illustrated the average diastolic blood pressure in the intervention group. It was $104.79 \mathrm{mmHg}$ and decreased to $92.84 \mathrm{mmHg}$. The result of paired t-test analysis in the intervention group showed a $p$-value $<0.05$, which means that there was a difference in systolic blood pressure before and after the intervention.

While the mean diastolic blood pressure in the control group was $106.20 \mathrm{mmHg}$, and it decreased into $101.85 \mathrm{mmHg}$. The result of paired t-test analysis in the control group showed a $p$-value $<0.05$, which means that there was a difference in diastolic blood pressure before and after the intervention.

Based on the result of the Independent t-test showed that the value of $p=0.597>0.05$, which means there was no difference in the average diastolic blood pressure between the intervention group and the control group before being treated. After the treatment, the result was $p=$ $0.004<0.05$, which means that there was a difference in the average diastolic blood pressure after being treated in both groups

\section{DISCUSSION}

The mean systolic blood pressure and diastolic blood pressure in the intervention group and the control group showed that there were no differences between the two groups before intervention with $\mathrm{p}=0.859$ and $\mathrm{p}=0.597$. Meanwhile, after treatment, it was obtained that there were differences between the two groups with $\mathrm{p}$ values $=0.000$ for systolic blood pressure and $\mathrm{p}=0.004$ for diastolic blood pressure.

The results of this research are in line with research conducted by ArifalAris (2018), which stated that the provision of bay leaf decoction could reduce blood pressure in hypertensive patients. The analysis showed $p=0.000$. At first, there were $7(21.9 \%)$ patients with moderate hypertension and decreased to $6(18.8 \%)$ patients after being given treatment. Furthermore, 16 patients or respondents, who experienced mild hypertension before being treated, changed to normal categories after being given a decoction of bay leaves.[11]

This was also supported by another study conducted by Sri Margowati (2016) that giving bay leaf decoction influenced the decrease in systolic and diastolic blood pressure $(\mathrm{p}<0.05)$ with an average reduction in systolic blood pressure of $24.97 \mathrm{mmHg}$ and diastolic blood pressure at $12.65 \mathrm{mmHg}$. This research showed the systolic mean value after being given intervention was 149.09 , and the diastolic mean value was 84.4.[12]

The content of flavonoids in bay leaves (Syzygiumpolyanthum) can help lower blood pressure by improving endothelial function and inhibiting platelet aggregation in humans, thus providing benefits, especially in cardiovascular disease.[12] Endothelium situated in the location between blood and smooth muscle of blood vessels and produces various substances that can maintain the homeostasis and health of blood vessels. Various things that damage the endothelium can cause endothelial dysfunction, resulting in hypertension and other cardiovascular diseases. Hypertension is a sign of damage to the endothelium associated with inflammatory response, oxidative stress, and dysfunction of the smooth muscle of the heart's blood vessels.[13]

Flavonoids are substances that can free radicals that inhibit lipid peroxide, prevent atherosclerosis, and provide cardioprotective effects. In a study by Houston on nutrition and supplementation for the treatment of hypertension, the recommended daily dose of flavonoids was 250 grams.[13]

\section{CONCLUSION}

Supplementation of $80 \mathrm{mg}$ dose of bay leaf nanoparticles (Syzygiumpolyanthum) for 14 days in pregnancy hypertensive patients who received nifedipine $10 \mathrm{mg}$ affected the reduction in systolic blood pressure by \pm $11.68 \mathrm{mmHg}$ and diastolic blood pressure of \pm 11.95 $\mathrm{mmHg}$ in the intervention group compared to with a control group. 


\section{ACKNOWLEDGMENT}

We are incredibly grateful for our supervisor in this research and the entire academic community of the Polytechnic of the Ministry of Health Semarang for the opportunity that has been given.

\section{REFFERENCES}

[1]. S. Gainder, M. Thakur, S. C. Saha, and M. Prakash, "To Study The Changes in Fetal Hemodynamics With Intravenous Labetalol or Nifedipine in Acute Severe Hypertension," Pregnancy Hypertens. An Int. J. Women's Cardiovasc. Heal., 2018.

[2]. WHO, World Health Organization Statistics. 2015.

[3]. S. Susiana, "Angka Kematian Ibu: Faktor Penyebab Dan Upaya Penanganannya," Pus. Penelit. Badan Keahlian DPR RI, vol. XI, no. II, 2019.

[4]. Dinas Kesehatan Provinsi Jawa Tengah, Profil Kesehatan Provinsi Jawa Tengah 2017, vol. 3511351, no. 24. Semarang: DKK Provinsi Jawa Tengah, 2018.

[5]. D. K. K. Brebes, Profil Kesehatan Kabupaten Brebes 2017. Jawa Tengah, 2017.

[6]. A. G. Kattah and V. D. Garovic, "The Management of Hypertension in Pregnancy," $A d v$. Chronic Kidney Dis., vol. 20, no. 3, pp. 229-239, 2013.

[7]. S. S. Hedayati, E. F. Elsayed, and R. F. Reilly, "Non-pharmacological aspects of blood pressure management: What are the data?," Kidney Int., vol. 79, no. 10, pp. 1061-1070, 2011.

[8]. M. D. Hidayati, T. Ersam, K. Shimizu, and S. Fatmawati, "Antioxidant Activity of Syzygium Polynthum Extracts," Indones. J. Chem., vol. 17, no. 1, pp. 49-53, 2017.

[9]. N. Jusnita and W. Syurya, "Karakterisasi Nanoemulsi Ekstrak Daun Kelor ( Moringa oleifera Lamk .)," J. Sains Farm. dan Klin., vol. 6, no. 1, pp. 16-24, 2019.

[10]. P. Dafriani, "Pengaruh Rebusan Daun Salam (Syzigium Polyanthum Wight Walp) Terhadap Tekanan Darah Pasien Hipertensi di Sungai Bungkal, Kerinci 2016," J. Med. Saintika, vol. 7, pp. 25-34, 2016.

[11]. A. Aris, "Pengaruh Pemberian Rebusan Daun Salam (Syzigium Polyanthum) Terhadap Penurunan Tekanan Darah Tinggi di Desa Plosowahyu Kecamatan Lamongan Kabupaten Lamongan," Pros. Semin. Nas., pp. 199-208, 2018.

[12]. S. Margowati, S. Priyanto, and M. Wiharyani, "Efektivitas Pengunaan Rebusan Daun Alpukat Dengan Rebusan Daun Salam Dalam Penurunan Tekanan Darah Pada Lansia," Universty Res. Coloquium, pp. 234-248, 2016.

[13]. M. Houston, "The role of nutrition and nutraceutical supplements in the treatment of hypertension," World J. Cardiol., vol. 6, no. 2, p. 38, 2014. 